\title{
The Effect of eWOM as Mediation of Website Quality and Trust
}

\author{
E Dita Septiari \\ Universitas Atma Jaya Yogyakarta \\ Email: ditaseptiari@staff.uajy.ac.id
}

\begin{abstract}
The purpose of this paper is to examine consumer attitudes toward online shopping in Marketplace, Shoppee. The paper used three variables which includes trust, perceived website quality, and electronic word of mouth (eWOM) along with their relationships in order to examine the effects of eWOM as mediator toward website quality and trust relationship. An offline survey was employed targeting online shoppers of Shoppee, one of reputable marketplace in Indonesia. A sample of 200 students in Universitas Atma Jaya Yogyakarta as online shoppers was involved in the online survey. Regression and Path analysis was used to test the hypothesized relationships of the research model. The empirical findings of this research shows that website quality and eWOM are predictor of consumer trust. Hence, EWOM also has mediation effect. The implication of this research is to support the importance of eWOM as key drivers to build trust among customers in online shopping. It also underlines the importance of website quality as important factors in online shopping.

Keywords: eWOM, Website quality, Trust, Online Shopping
\end{abstract}

JEL : M31

DOI $\quad: 10.24002 /$ kinerja.v22i2.1809

Received : 25-08-2018 Reviewed: 06-09-2018 Final Version: 07-09-2018

\section{INTRODUCTION}

The number of internet users in Indonesia has risen exponentially. In 2015, 89.32 million people were accessing the internet in Indonesia, and in 2017 have grown until 104.96 million, and it is projected to increase to 133.39 million in 2021. Indonesia now becomes one of the biggest online markets worldwide (https://www.statista.com/statistics/254456/number-of-internet-users-in-indonesia). Based on (Das et al., 2016), Indonesia is in nascent stage of digitization but has long way to go digital age because it constrained by limited access to the technology, low penetration of internet, and the limited of credit card. 
The Indonesians are netizens in every sense of the word, with a need for constant connectivity, instant information, and a growing appetite for digital content. They spend a higher-than-average amount of time on the Internet, primarily engaging in heavy social media usage and e-commerce. Their social media usage is among the highest of any population in the world. In 2016, revenue of ecommerce in Indonesia amounted to USD 6 billion, 78 percent of current Internet users made online purchases. The industry is expected to grow by approximately 18 percent annually in the next five years, reaching a market volume of USD 16.4 billion by the end of 2020 (Das et al., 2016).

The shift in online behaviour from desktop to mobile that occurs has opened up new opportunities. One of the market place that takes advance from these opportunities is Shopee. Shopee facilitates the buyers and sellers transaction via mobile devices with Android and IOS operating systems (Priambada, 2015). It is a platform tailored for the region, providing customers with an easy, secure and fast online shopping experience through strong payment and logistical support. Shopee is Singapore e-commerce company that entered the Indonesian market since 2015. Indeed, Shopee is not only present in Indonesia but also Singapore, Malaysia, Thailand, Vietnam, and Phillipines. In general, Shoppee positioning their company as mobile social commerce. Southeast Asia is a region that adore to play social media. Today, this application has been downloaded by more than 25 million and more than 1 millions sellers and brand. The Shoppee CEO said that the influencer, and the quality of shoppee becomes the key of consumer growing (Sholihin, 2018).

This research examines attitudes of consumers toward Shoppee application within the context of college students in Yogyakarta whom can be considered as early adopters in Shoppee users. Early adopters are important to investigate that their roles affects the next adoption of other consumers based on the information and views of early adopters (Al-Debei, et al., 2015). The decision of other consumers on whether to adopt an innovation or not is greatly influenced by opinions of others (Al-Debei, et al., 2015).

Transaction in internet is characterized by many risks and uncertainty for customers. Based on prospect theory, human decisions under conditions of risk and uncertainty will avoid the uncertainty risk and try to get maximization benefit. Therefore trust is very important to decrease the risks of uncertainty in customers perception. Lack of trust has been shown to prevent consumers from purchasing online and to abandon their shopping cart during an online transaction ( (Neveen \& Ragowsky, 2008). Trust can remove the barriers of consumers perception toward online risk transaction and decrease the risks of uncertainty in customers perception.

The purpose of this research is to investigate the impact of website quality and eWOM toward consumer trust. Finally, this also explores the mediating role of eWOM in website quality and trust relationship and gender a moderation role in the model. 


\section{LITERATURE REVIEW}

\subsection{Theoretical Foundation}

Prospect theory explains human decisions under conditions of risk and uncertainty from a value maximization perspective (Kahneman \& Tversky, 1979). Prospect theory explains how people calculate more weight on positive outcomes that are considered certain than positive outcomes from uncertain probable. This illustrate why most of people are risk averse, who tend to prefer an option with certain but lower benefit over an option with uncertain but higher benefit (Kim, et al., 2012). Transaction in internet is characterized by many risks and uncertainty for customers. For internet shopping, risk is another important nonmonetary aspect because customer deception by internet vendors is becoming increasingly common (Kim, et al., 2012). Therefore trust is very important to decrease the risks of uncertainty in customers perception. Trust is crucial in many such transactional, buyer-seller relation-ships, especially those containing an element of risk, including interacting with an e-vendor, and inability to visit physical store and examine the product they are interested in buying (Gefen, et al., 2003).

\subsection{Trust}

Trust has been examined in numerous studies in many different fields such as economics, management, technology, psychology, social and institutional contexts (Kim, et al., 2012). Prior literature has defined trust as behavioral intentions that result from a general belief in an online retailer, or a specific beliefs in competence, integrity and benevolence (Neveen \& Ragowsky, 2008). Trust is based on the buyer's expectations that the seller will not have an opportunistic attitude and take advantage of the situation, but will behave in a dependable, ethical and socially appropriate manner. Trust deals with the belief that seller will fulfil its commitments despite the buyer's vulnerability and dependence (Gefen, et al, 2003). Consumer trust refers to consumers willingness to engage in a shopping transaction with the retailer ( $\mathrm{Li}$, et al., 2014). Trust determines the nature of many business and the social order.

Some studies suggested that customers with low trust tend to have negative views when faced with risky situations. On the other hand, customers with high trust tend to have positive views and are willing to try new things (Agag \& El-Masry, 2016). Trust plays a crucial role in determining online purchasing intentions, prerequisite for successful commerce ( $\mathrm{Li}$, et al., 2014). Trust promotes transaction success because it can reduce social uncertainties that would otherwise be too complex, so it becomes a key predictor of both initial online purchase and repeat purchase ( (Fang, et al., 2014). According to Komiak and Bembasat (2006) as cited from Li, et al.,(2014), cognitive trust (which focuses on consumers' beliefs based on rational expectations of online retailers' attributes) impacts on emotional trust (which 
addresses consumer attitudes and emotional feelings), which further impacts upon purchase intention.

\subsection{EWOM (Electronic Word of Mouth)}

Word of mouth is the exchanging of marketing information between consumers in such a way that it plays a fundamental role in shaping their behaviour and in changing attitudes toward product and services (Huete-Alcocer, 2017). eWOM is all informal communication via the internet addressed to consumers and related to the use or characteristics of goods or services or the sellers. The advantage of this tool is that it is available to all consumers, who can use online platforms to share their opinions and reviews with other users (Huete-Alcocer, 2017). With the growth of social media and digital channels, the influence of eWOM expanded exponentially, reach over a worldwide network. The eWOM messages are conveyed more quickly between users at any time via internet. eWOM in many types such as online notifications, reviews, opinions and recommendations has become a source information for customers before, during and after consuming a given product or service. eWOM also offers benefit to company to identify customers' needs and perception and a cost effective way to communicate with them. eWOM is seen as a reliable and impartial source of information (Ladhari \& Michaud, 2015). eWOM can shapes consumers expectation, influences preferences and attitudes, and affects purchasing decisions and post use evaluation (Luo and Zhong, 2015 in Ladhari \& Michaud, 2015).

\subsection{Perceived Website quality}

A company web site is an essential tool for communicating information about product and services. Perceived website quality refers to the quality and overall performance of an online shopping web site. Perceived website quality can be defined as the desirable characteristics of an online shopping web site as perceived by online shoppers (Al-Debei, et al., 2015). Similarly, according to (Gefen, et al., 2003) defined perceived website quality as the degree to which a consumer perceives that the web site's features and characteristics meet his/her needs and requirements. Perceived website quality can be measure based on the web site design and process which is simple, smooth, reliable, and effective (Al-Debei, et al., 2015). According to Aladwani and Palvia ( in Al-Qeisi, et al., 2014) perceived website quality is define as users' evaluation of a website's features that meet their needs and reflect overall excellence of the website. According to Al-Qeisi, et al., (2014), website quality divided into four sub dimensions. The first component is technical dimension (refers to website characteristics such as security, search facilities, site availability, valid links, personalization or customization, speed of page loading, interactivity, and ease of access); the second component is general content (characteristics such as content usefulness, completeness, clarity, currency, conciseness, and accuracy); the third is specific content (refers to characteristics such as contact information, general company information, product/service details, consumer policies, and customer support), and the final component is appearance 
(refers to characteristics such as attractiveness, organization, proper use of fonts, colors, and proper use of multimedia).

\subsection{Perceived Website Quality and Trust}

A website is the primary communication channel between customers and companies; therefore the website's quality plays a crucial role in the success (Agag \& El-Masry, 2016). Previous studies have shown that the perception of a consumer about the quality of an online shopping web site have impact on the consumers' perceptions about the benefits that can be gratified by using the web site. The higher perception of quality formed the positive impression of website (Al-Debei, et al., 2015). The online consumers are likely to purchase from online website that they can trust because they recognise the quality of the provided products and services. The positive link between website quality and consumer trust has been confirmed by prior studies (Al-Debei, et al., 2015; Agag \& El-Masry, 2016, Al-Qeisi, et al., 2014). Accordingly, the following hypothesis has been posited:

H1: Website quality positively influences consumers' trust

\subsection{Word of Mouth as Mediation of Website quality and Trust}

When consumers perceive the quality of an online shopping web site to be high in terms of design, navigation, and search facilities, they would be more encouraged to post positive eWOM comments. Positive eWOM comments are perceived to be credible and trustworthy by internet users (Al-Debei, et al., 2015). Online opinions and recommendations become important things whereby online shoppers can seek new information with great persuasiveness effect on internet users (Ladhari \& Michaud, 2015). According to Al-Debei, et al., (2015), word of mouth become mediation of website quality and trust. Accordingly, the following hypothesis has been posited:

$\mathrm{H}$ 2: eWOM become mediation of website quality and trust relationship.

\subsection{Gender}

Sociolinguistic theory suggests that men and women have different underlying social objectives when communicating (Neveen \& Ragowsky, 2008). According to (Fan \& Miao, 2012), in virtual communities, gender plays an important role in communication and e-commerce transactions. Women use the internet to give and receive social support. Their communication is typically focused on cooperation and network-oriented collaboration. Their e-commerce transactions are more emotional. Men use the internet to increase and protect social position. Their communication and e-commerce transactions are more pragmatic. Online WOM systems are focused on sharing of information about product. Men will likely perceive the information from eWOM beneficial and they will trust to the online website. The differences between women and men in has been confirmed by prior studies (Neveen \& Ragowsky, 2008, Fan \& Miao, 2012 ). Accordingly, the following hypothesis has been posited: 
H3: The effect of eWOM and website quality on trust will be significantly different in magnitude because of gender.

Figure 1 illustrates the framework in which website quality elements impact trust and mediated by eWOM. Website quality is positively related to trust and eWOM, and eWOM is positively relate to trust.

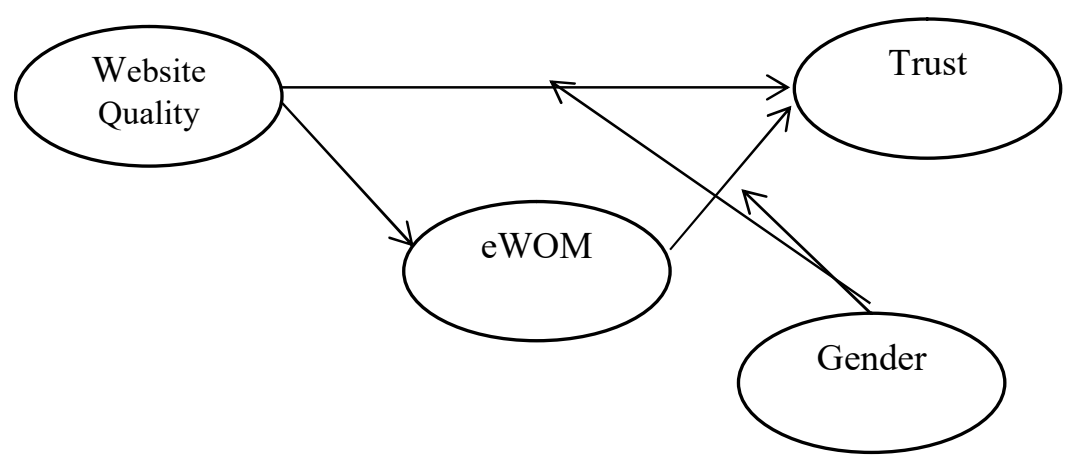

Figure 1. Research Framework

\section{METHODOLOGY}

\subsection{Research Population and Sample}

The research population is Indonesian who has been used Shoppee to purchase goods or services. However it was possible to access Shoppee customer database or any other databases from internet. Therefore with efficiency reason, this research used college students in Yogyakarta whom can be considered as early adopters in Shoppee users as sample. Convenience sampling method was selected for data collection process using an online survey. Using convenienc sampling is efficient and acceptable and relevant for multivariate data analysis purposes (AlDebei, et.al., 2015). The sample were selected based on experience as Shoppee consumers. The questionnaire were directed to respondents who have online purchase experience in Shoppee. The reseacher receipt 200 questionnaire, but only 186 that can be used. Therefore the sample size of this research is 186 respondents.

\subsection{Measurement Items}

All of the questionnaires were adapted from Al-Debei, et.al., (2015). Some of the measurement items wording was modified to fit the context of this study. All the research constructs were measured on five-point Likert-type scales ranging from 5 "Strongly Agree" to 1 "Strongly Disagree." A questionnaire also has small section to investigate the respondents' characteristics. Table 1 shows constructs' measurement items and their sources of operationalization. 
Table 1. Variables Measurements and Items

\begin{tabular}{|c|c|}
\hline Variables & Items Measuring Variables \\
\hline $\begin{array}{l}\text { Website Quality } \\
\text { (WQ) } \\
\text { Source: Al-Debei, } \\
\text { et.al., (2015) }\end{array}$ & $\begin{array}{l}\text { 1. The marketplace internal browsing meets my needs } \\
\text { 2. The ordering process used by the marketplace is simple } \\
\text { 3. The marketplace web page content quickly loads } \\
\text { 4. The marketplace internal search capabilities meets my needs } \\
\text { 5. Little search effort is needed to find the needed } \\
\text { products/information in the marketplace retailer page } \\
\text { 6. Overall, this market place is well-designed }\end{array}$ \\
\hline $\begin{array}{l}\text { eWOM } \\
\text { Source: Al-Debei, } \\
\text { et.al., (2015) }\end{array}$ & $\begin{array}{l}\text { 1. I often read online recommendations to buy products from this } \\
\text { online marketplace } \\
\text { 2. I often post positive online comments about this online } \\
\text { marketplace. } \\
\text { 3. I often read positive online reviews about the products of this } \\
\text { online retailer in marketplace. } \\
\text { 4. My e-community frequently post online recommendations to buy } \\
\text { from this marketplace. } \\
\text { 5. When I buy a product from this marketplace, consumer's online } \\
\text { recommendations and reviews make me more confident in } \\
\text { purchasing the product. }\end{array}$ \\
\hline $\begin{array}{l}\text { Trust } \\
\text { Source: Al-Debei, } \\
\text { et.al., (2015) }\end{array}$ & $\begin{array}{l}\text { 1. It is safe to pay money and perform a financial transaction on this } \\
\text { marketplace. } \\
\text { 2. The online marketplace will protect my financial-related information } \\
\text { from being leaked (hacked). } \\
\text { 3. The market place web site is secured given that it uses digital } \\
\text { certificate. } \\
\text { 4. Market place web site will not sell my personal information (e-mail, } \\
\text { phone number, names..) to others for commercial use }\end{array}$ \\
\hline
\end{tabular}

The questionnaire was originally constructed in English and then translated into Indonesian language.

\section{RESULT AND DISCUSSION}

\subsection{Validity and Reliability}

The validity of the research instrument was assessed through Confirmatory factor analysis. CFA was used to investigate construct validity. According to Hair, et al., (2014) the factor loading \pm 0.50 or greater are considered practically significant. Table 2 shows the result of factor analysis. The Barlett's test is significant, indicates the presence of nonzero correlations, not the pattern of these correlations. The factor has been loading in three variables as in the theory therefore the entire factor is acceptable. However, eWOM 2 is unacceptable because the factor loading less than 0.5 which means not valid and cannot be used to reflect the eWOM variable. 
Table 2. The Result of Validity Analysis

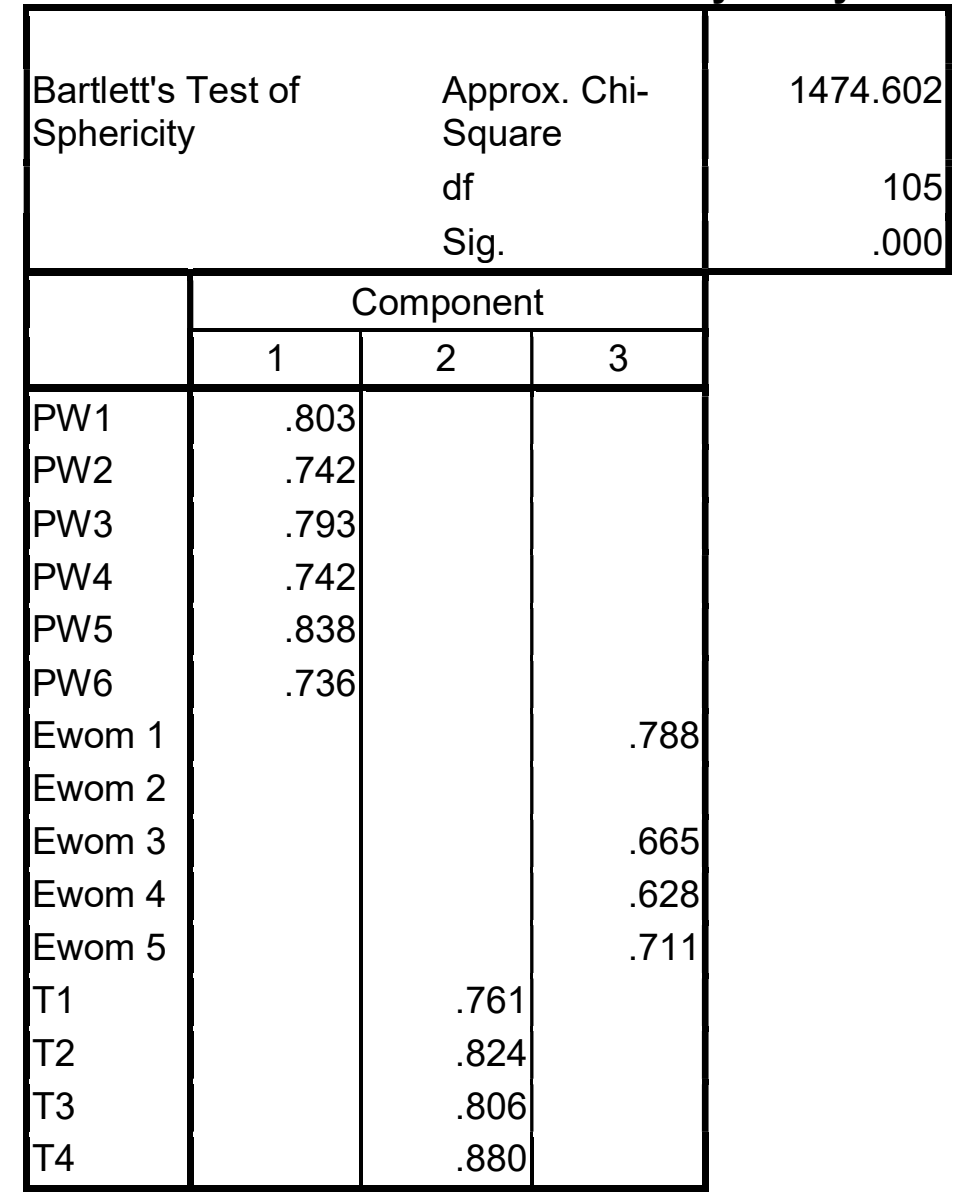

Table 3 shows the result of reliability analysis using Cronbach alpha. The variable is reliable if the Cronbach alpha exceed 0,6 . The reliability indicators value were all between 0.78 and 0.931 , which greater than 0.7 means all of the questions were reliable.

Table 3. The Result of Reliability Analysis

\begin{tabular}{l|l}
\hline Variables & Cronbach's Alpha \\
\hline Website Quality & 0.931 \\
eWOM & 0.786 \\
Trust & 0.894 \\
\hline
\end{tabular}

\subsection{Research sample demographic profile}


Table 4 exhibits the detailed research sample based on gender, age, and the frequency using Shoppee. Noticeably, table 4 shows that $52,2 \%$ of the sample are female, almost a half of the sample are aged $19-23$ years, and $51,1 \%$ of the sample bought from two to four times using Shoppee. these results and characteristics are important indicators for the online shopping behaviour.

Table 4. Sample Profile

\begin{tabular}{l|l|l|l}
\hline Measure & Item & Frequency & Percentage \\
\hline \multirow{2}{*}{ Gender } & Male & 89 & $47,8 \%$ \\
& Female & 97 & $52,2 \%$ \\
Age & Less than 19 & 42 & $22,6 \%$ \\
& $19-23$ & 104 & $55,9 \%$ \\
Frequency & More than 23 & 40 & $21,5 \%$ \\
transaction in & 1 & 29 & $15,6 \%$ \\
Shoppee & $2-4$ & 95 & $51,1 \%$ \\
\hline
\end{tabular}

\subsection{Hypotheses Testing}

SPSS was used to complete single and multiple regression analysis of survey results. The hypotheses testing analysis for all respondents (186) is shown in table 5. The mediation analysis is tested based on Baron and Kenny (1986) and Zhao, et al. (2010). The procedures contains three following regression equations. The first the independent variable must affect the dependent variable. The second, the independent variable must affect mediator variable. The third regressing the dependent variable on both the independent variable and the mediator, and the mediator must affect the dependent variable (Baron \& Kenny, 1986). According to Zhao, et al. (2010), there are three patterns consistent with mediation and two with non-mediation:

i. Complementary mediation: Mediated effect $(a \times b)$ and direct effect $(c)$ both exist and point at the same direction.

ii. Competitive mediation: Mediated effect $(a \times b)$ and direct effect $(c)$ both exist and point in opposite directions.

iii. Indirect-only mediation: Mediated effect $(a x b)$ exists, but no direct effect.

iv. Direct-only nonmediation: Direct effect $(c)$ exists, but no indirect effect.

v. No-effect nonmediation: Neither direct effect nor indirect effect exists. 
Table 5. Regression Analysis For Website Quality and Trust Relationship

\begin{tabular}{|c|c|c|c|c|c|}
\hline Stages & $\begin{array}{l}\text { Independent } \\
\text { Variable }\end{array}$ & $\begin{array}{l}\text { Dependent } \\
\text { Variable }\end{array}$ & $F$ & $\begin{array}{l}\text { Adj R } \\
\text { Square }\end{array}$ & $\begin{array}{c}\text { Standardized } \\
\text { Beta }\end{array}$ \\
\hline 1 & $\begin{array}{l}\text { Website } \\
\text { Quality }\end{array}$ & Trust & $84,702^{\star *}$ & 0,312 & $0,561^{* *}$ \\
\hline 2 & $\begin{array}{l}\text { Website } \\
\text { Quality }\end{array}$ & eWOM & $139,184^{* *}$ & 0,428 & $0,656^{* *}$ \\
\hline \multirow[t]{2}{*}{3} & eWOM & \multirow[t]{2}{*}{ Trust } & \multirow[t]{2}{*}{$48,599^{* *}$} & \multirow[t]{2}{*}{0,340} & $0,236^{* *}$ \\
\hline & $\begin{array}{l}\text { Website } \\
\text { Quality }\end{array}$ & & & & $0,407^{* *}$ \\
\hline
\end{tabular}

Table 5 exhibits the result of regression analysis. Based on this table, website quality has positive impact on trust, therefore $\mathrm{H} 1$ is significant. In confirmation of $\mathrm{H} 2$, eWOM partially mediated the impact of website quality toward trust because all of three stages are significant. Figure 2 shows the mediator model of eWOM. Based on figure 2 and table 5 , the $a=0,656, b=0,236, c=0,407$, then the indirect path is formulated: $c^{\prime}=(a \times b)+c$. the calculation is $(0,656 \times 0,236)+0,407$ which equals to 0,561816 . According to Zhao, et al. (2010), the mediation type is complementary mediation.

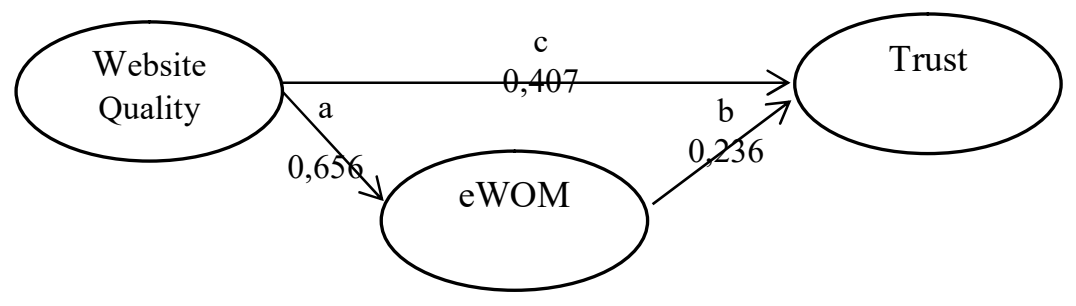

Figure 2. The Mediation Model of eWOM

The third hypothesis is analysed using sub groups, which divided the data based on gender, male and female. The result is in table 6 . The table indicate that the adjusted $R^{2}$ from group female and male are different. The adjusted $R^{2}$ from group male is bigger than female, means that the model for male is more predictive. Based on chow test, the moderation is not significant, there are no differences between male and female model. Previous studies showed that males are more pragmatic during the purchasing process; females are more emotional during the 
purchasing process (Fan \& Miao, 2012; Neveen \& Ragowsky, 2008). This finding confirmed the previous studies. Males only rely with website quality to develop their trust. The finding also shows the importance of trust related to the degree to which a person depends on other people (Neveen \& Ragowsky, 2008). The more a person depends on others, the greater that person's need to trust. This result confirmed that women who show greater reliance on networks of people, place a greater emphasis on eWOM to trust the marketplace.

Table 6. Regression Analysis with Female as Moderator

\begin{tabular}{|c|c|c|c|c|c|c|}
\hline Stages & $\begin{array}{l}\text { Independent } \\
\text { Variable }\end{array}$ & $\begin{array}{l}\text { Dependent } \\
\text { Variable }\end{array}$ & $\begin{array}{l}\text { Sum of } \\
\text { squares } \\
\text { residual }\end{array}$ & $\mathrm{F}$ & Adj $R^{2}$ & $\begin{array}{l}\text { Standardized } \\
\text { Beta }\end{array}$ \\
\hline \multirow{2}{*}{$\begin{array}{l}1 . \\
\text { (regression } \\
\text { with all data) }\end{array}$} & eWOM & \multirow[t]{2}{*}{ Trust } & \multirow[t]{2}{*}{68,216} & $48,599^{* *}$ & 0,340 & $0,236^{* *}$ \\
\hline & Website Quality & & & & & $0,407^{\star *}$ \\
\hline \multirow{2}{*}{$\begin{array}{l}2 . \\
\text { Regression } \\
\text { with female } \\
\text { data }\end{array}$} & eWOM & \multirow[t]{2}{*}{ Trust } & \multirow[t]{2}{*}{34,005} & \multirow[t]{2}{*}{$15,022^{* *}$} & \multirow[t]{2}{*}{0,226} & $0,283^{\star *}$ \\
\hline & Website Quality & & & & & $0,274^{* *}$ \\
\hline \multirow{2}{*}{$\begin{array}{l}3 . \\
\text { Regression } \\
\text { with Male } \\
\text { data }\end{array}$} & eWOM & \multirow[t]{2}{*}{ Trust } & \multirow[t]{2}{*}{33,207} & \multirow[t]{2}{*}{$32,611^{* *}$} & \multirow[t]{2}{*}{0,418} & 0,171 \\
\hline & Website Quality & & & & & $0,522^{\star \star}$ \\
\hline 4. Chow test & \multicolumn{6}{|c|}{$\begin{array}{l}\text { SSRr }=68,216 ; \text { SSRur }(34,005+33,207) ; \mathrm{n} 1=97, \mathrm{n} 2=89 ; \mathrm{k}=2 \\
\text { With formula: } \\
\mathrm{F} \text { count }=\frac{(\text { SSR } r-S S R u r) / k}{(\operatorname{SSR} u r /(n 1+n 2-2 k)}=\frac{(68,216-67,212) / 3}{67,212 /(182)}=0,896 \\
\mathrm{~F} \text { table }(3,180)=2,66 \\
\mathrm{~F} \text { count }<\mathrm{F} \text { table, the moderation is not significant } \\
* * \text { significant in } \alpha=0,05\end{array}$} \\
\hline
\end{tabular}

\section{CONCLUSION}

Overall, the research investigates the effect of web quality, eWOM, toward trust in online transaction, and the role of eWOM as mediation. The research shows that web quality has positive impact toward trust, and eWOM become complementary mediation with positive effect in web quality and trust relationship. Web quality plays a more significant role to build trust among customers.

The research is failed to show the differences of gender in model, but the interesting finding in expanding model can become insight for company especially Shopee. The different heightened levels of online trust differ across genders. Males only considered web quality to develop trust in Shoppee. In other hand, females considered web quality and eWOM to develop trust in Shopee, and eWOM plays 
more effect toward trust than web quality. This result confirmed the theory that females rely on networks of people to build trust.

Online companies can study this research to heighten the customer's trust. Companies must strive to maintain and improve their web quality based on design and process which is simple, smooth, reliable, and effective. Companies also can provide more online product information to increase the balance between actual product information and consumer reviews because eWOM can strengthen the effect of web quality toward trust. Companies also can manage the forum to encourage information collaboration between female's customers.

\section{LIMITATION}

The model used in this study had several limitations. The first, online surveys were used to collect the data, it can caused bias because researcher cannot understand the sincerity of respondents to answer questionnaire. The second, the adjusted $\mathrm{R}$ square are less than 0,5 means the model was not really proper to describe the trust variable, it needs others variables to understand more about trust. The third, the model did not considered the moderating effects of gender differences due to the small sample size. As a result the models failed to provide strong evidence that gender differences had effect on the model. Finally, the models only considered one marketplace therefore this model is limited to be generalized. For future work, is needed to verify the study for other types of product with added some variables such as consumer experiences, perceived ease of use, perceived usefulness, etc.

\section{REFERENCE}

Agag, G. M., \& El-Masry, A. A. 2016. Why Do Consumers Trust Online Travel Websites? Drivers and Outcomes of Consumer Trust toward Online Travel Websites. Journal of Travel Research, pp 1-23.

Al-Debei, M. M., Akroush, M. N., \& Ashouri, M. I. 2015. Consumer Attitudes towards Online Shopping, The effect of Trust, Perceived Benefits, and Perceived Web Quality. Internet Research, Vol 25, No 5, pp 707-733.

Al-Qeisi, K., Dennis, C., Jayawardhena, C., \& Alamanos, E. 2014. Website Design Quality and Usage Behavior: an Application of the UTAUT. Journal of Business Research, Vol. 67(11), pp: 2282-2290.

Baron, R. M., \& Kenny, D. M. 1986. Moderator-Mediator Variables Distinction in Social Psychological Research: Conceptual, Strategic, and Statistical Considerations. Journal of Personality and Social Psychology, Vol 51, (6) pp 1173-1182.

Das, K., Gryseels, M., Sudhir, P., \& Tan, K. T. 2016. Unlocking Indonesia's Digital Opportunity. Jakarta: McKinsey Indonesia. 
Fan, Y.-W., \& Miao, Y.F. 2012. Effect of Electronic Word-Of-Mouth on Consumer Purchase Intention: The Perspective of Gender Differences. International Journal of Electronic Business Management, Vol. 10, No. 3, pp. 175-181.

Fang, Y., Qureshi, I., Sun, H., McCole, P., Ramsey, E., \& Lim, K. H. 2014. Trust Satisfaction, and Online Repurchase Intention: The Moderating Role of Perceived Effectiveness of E-Commerce Institutional Mechanisms. MIS Quarterly, Vol. 38 No 2, pp.407-427.

Gefen, D., Karahanna, E., \& Straub, D. W. 2003. Trust and TAM in Online Shopping: An Integrated Model. MIS Quarterly, Vol. 27, No. 1, pp. 51-90.

Hair, J. F., Black, J. W., Babin, B. J., \& Andersen, R. E. 2014. Multivariate Data Analysis 7th edition. England: Pearson.

Huete-Alcocer, N. (2017, July 25). A Literature Review of Word of Mouth and Electronic Word of Mouth: Implication of Consumer Behavior. Mini Review Frontiers in Psychology, Vol. 8, pp. 1256-1260.

Kahneman, D., \& Tversky, A. 1979. Prospect Theory: An Analysis of Decision under Risk. Econometrica, Vol 47, No 2, pp. 263-291.

Kim, H.-W., Xu, Y., \& Gupta, S. 2012. Which is more important in Internet shopping, perceived price or trust? Electronic Commerce Research and Applications. pp. 241-252.

Ladhari, R., \& Michaud, M. 2015. eWOM Effects on Hotel Booking Intentions, Attitudes, Trust, and Website Perceptions. International Journal of Hospitality Management, No 46, pp. 26-45.

Li, H., Jiang, J., \& WuSchool, M. 2014. The effects of trust assurances on consumers' initial online trust: A two-stage decision-making process perspective. International Journal of Information Management, Vol. No 34, pp. 395-405.

N. F., \& Ragowsky, A. 2008. Establishing Trust in Electronic Commerce Through Online Word of Mouth: An Examination Across Genders. Journal of Management Information Systems, Vol. 24, No. 4, pp. 101-121.

Zhao, X., JR, J. G., \& Chen, Q. 2010. Reconsidering Baron and Kenny: Myths and Truths about Mediation Analysis. Journal of Consumer Research, Vol 37, pp.197-206. 


\section{INTERNET SOURCES}

Number of internet users in Indonesia from 2015 to 2022 (in millions). 2018. accessed 13 July 2018 from www.statista.com https://www.statista.com/statistics/254456/number-of-internet-users-inindonesia/

Priambada, A. (2015, 06 22). Daily social. Accessed 16 August 2018, from www.dailysocial.id: https://dailysocial.id/post/shopee

Sholihin, B. (2018, 01 31). Tempo. From www.indonesiana.tempo.co: https://indonesiana.tempo.co/read/122160/2018/01/31/burhan_sholihin.1 